\title{
Considerações morais sobre o imposto
}

\author{
Eric Villac Pinheiro ${ }^{\mathrm{I}}$ (D0000-0002-2836-7272
}

Ibmec, São Paulo, SP, Brasil

Resumo: O presente texto busca apresentar as posições de diferentes correntes de pensamento quanto à tributação. Iniciando a confrontação entre as correntes ao longo da história, pela apresentação da corrente da teologia católica; seguido de como a lei natural responde à questão da moralidade nos impostos, assim como a visão escolástica sobre o problema, o pensamento dos liberais clássicos e da escola austríaca, e por fim, no intuito de colocar a questão na contemporaneidade, buscando responder se a cobrança de imposto é justa ou não.

Palavras-chave: justiça nos impostos, escolástica, liberais clássicos, escola austríaca de economia. 


\title{
Moral Considerations about taxation
}

\begin{abstract}
This paper presents the positions of different currents of thought regarding taxation. Initiating the confrontation between the currents throughout history, by presenting the current of Catholic theology; followed by how natural law answers the question of tax morality, as well as the scholastic view on the problem, the thinking of the classical liberals and the Austrian school, and finally, in order to put the question in contemporary, seeking to answer whether Tax collection is just or not.
\end{abstract}

Keywords: justice on taxation, scholastics, classical liberals, Austrian school of economic.

\section{Consideraciones Morales sobre impuesto}

Resumen: Este artículo presenta las posiciones de diferentes corrientes de pensamiento con respecto a los impuestos. Iniciando la confrontación entre las corrientes a lo largo de la historia, presentando la corriente de la teología católica; seguido de cómo la ley natural responde a la cuestión de la moralidad en impuestos, así como la visión escolástica sobre el problema, el pensamiento de los liberales clásicos y la escuela austriaca, y finalmente, para plantear la pregunta en el contemporáneo, buscando responder si La recaudación de impuestos es justa o no.

Palabras clave: justiciar en impuestos, escolástica, liberales clásicos, Escuela Austriaca de Economía. 


\section{Introdução}

No estudo da justiça do tributo, primeira coisa que se nota é que não é um problema moderno, embora tenha ganhado maior notoriedade, da parte dos liberais, com os autores como Rothbard e Hoppe pelas suas críticas. O problema perpassa desde sua criação e há de continuar, porque trata-se de um desconforto corpóreo, ou melhor, metálico e de cédulas- em suma, sensível.

Como diz o provérbio popular: só se incomoda alguém quando dói no bolso. Entretanto, não é algo que se assimile por osmose, partindo-se apenas do momento presente para compreender a questão. Torna-se necessário retroceder alguns séculos para observar seu desenvolvimento conforme a situação concreta que cada grupo de pensadores se defrontou e buscou encontrar as respostas às suas questões quanto ao tributo.

\section{1. “A questão armadilha" dos impostos feita a Cristo}

A pergunta foi feita pelos discípulos dos fariseus e dos herodianos, que buscavam prender Jesus Cristo, em suas próprias palavras, num sermão - conhecido como a parábola da Festa de Casamento. Logo, perguntaram, se era lícito ou não pagar tributos a César. Jesus Cristo os chama nesse momento de hipócritas. Eles haviam confundido a autoridade de Cristo, com a autoridade de um rei da terra.

Na Catena Aurea ${ }^{1}$, Teófilo de Antioquia explica esse momento histórico:

Entendiam (os fariseus), portanto, que se dissesse ser apropriado pagar tributo à César, o povo O acusaria de sujeitá-los à escravidão, e se dissesse que não era lícito pagar o tributo, podiam apresenta-Lo como um revolucionário ao governador. Mas Se livrou dessas amarras. (DE AQUINO, 2016, s/p)

Outra do mesmo santo é: "As necessidades inevitáveis dos nossos corpos são também como as de César, o Senhor manda que demos ao corpo as roupas e o alimento necessário, e a Deus o que é de Deus (como as vigílias, as orações, etc)" (DE AQUINO, 2016, s/p).

Parece com isso, como diz São Tomás de Aquino, exagerado afirmar que todos os reis pecam por roubo, já que isso condenaria quase todos, porque extorquem violentamente os bens dos súditos. Algo que não parece ser verdade, já que Davi, Salomão, São Luís IX e São Fernando III de Castela foram reis.

São Tomás responde à objeção, da seguinte forma:

Os governantes que exigem por justiça dos súditos o que estes lhes devem, para a conservação do bem comum, não cometem rapina, mesmo se violentamente o exigirem. Os que porém extorquirem indebitamente, por violência, cometem tanto rapina como latrocínio. Por isso, diz Agostinho: Posta de parte a justiça, que são os reinos senão grandes latrocínios? Pois, por seu lado, que são os latrocínios senão pequenos reinos? E a Escritura: Os seus príncipes eram no meio dela como uns lobos que arrebatam a sua presa. E portanto, estão, como os ladrões, obrigados à

${ }^{1}$ Livro que compila os comentários dos Padres da Igreja sobre o Evangelho. 
restituição. E tanto mais gravemente pecam que os ladrões, quanto mais perigosa e geralmente agem contra a justiça pública, da qual foram constituídos guardas. (DE AQUINO, 2016, s/p)

Disso, depreende-se que o tributo, por poder se tratar, em certos casos de uma rapina, ou seja, um ato de tomar algo de alguém, quando aquilo tomado não o pertence, e, sendo indevido, implicando uma certa violência e coação; ou, se no caso de empréstimo, o proprietário não iria concedê-lo, uma relação conflituosa, dessa forma, torna difícil delimitar as linhas entre o devido e indevido.

Parece que, para o rei e seus servos, a quantidade de tributo é insuficiente, enquanto que, para os súditos, excessiva (CHAFUEN, 2009, p. 147), de modo que os príncipes desejam o aumento de tributos, para poderem sustentarem suas ações e a vida de amparados pelo seu governo, enquanto os súditos desejam que se diminua. No final das contas, os impostos tendem a aumentar com o tempo. Isso decorre do aumento das atividades e complexidade da mesma parte do Estado, ao longo da história.

Outro momento, importante na história da Revelação, é quando os judeus, ao saberem que Jesus Cristo entrou na casa de Zaqueu, o publicano, queixaram-se, dado seu trabalho de coletor de impostos. Zaqueu afirmou, após receber Jesus, que devolveria quatro vezes mais a alguém que, porventura, houvesse extorquido². Outrossim, o próprio Jesus Cristo, ao ser entregue pelos Sumos Sacerdotes, é falsamente acusado de proibir o pagamento de impostos ao imperador e denominar-se Cristo $\mathrm{Rei}^{3}$. O ramalhete para este artigo é a Palavra: "Reddite ergo, quae sunt Caesaris, Caesari et, quae sunt Dei, Deo"', buscando delimitar, nas correntes de pensamento, esta justa medida.

Esta frase exige apresentar alguns conceitos sobre a diferença entre o poder do Rei dos reis e dos reis da Terra. É a diferença entre a civilização judaica-cristã e a pagã, quanto ao poder do rei para cobrar tributos. Alguns documentos da Santa Igreja apresentam essa separação. A bula Unam Sanctam (1302), do Santo Padre Bonifácio VIII, apresenta o seguinte ensinamento: "As palavras do Evangelho nos ensinam: esta potência comporta duas espadas, todas as duas estão em poder da Igreja: a espada espiritual e a espada temporal. Mas esta última deve ser usada para a Igreja enquanto que a primeira deve ser usada pela Igreja. $\mathrm{O}$ espiritual deve ser manuseado pela mão do padre; o temporal, pela mão dos reis e cavaleiros, com o consenso e segundo a vontade do padre. Uma espada deve estar subordinada à outra espada; a autoridade temporal deve ser submissa à autoridade espiritual" (BONIFÁCIO, s/d).

Bonifácio VIII, em seu papado, também trava um confronto com o rei Felipe, o Belo, por causa da desobediência do rei à Igreja - este que viria a dissolver a Ordem Templária, e que teve como avô o rei São Luís IX. O conflito se iniciou quando o rei decidiu tributar os bens eclesiásticos. A primeira reação do Papa foi expressa na bula Clerics Laicos (1296), na qual proibiu a França e a Inglaterra a tributarem contra os bens da Igreja, advertindo-as da pena

\footnotetext{
${ }^{2}$ Evangelho Segundo São Lucas $(19,7)$.

${ }^{3}$ Evangelho Segundo São Lucas $(23,2)$.

4 “Dai, pois, a César o que é de César e a Deus o que é de Deus”, contido em São Mateus, 22. (BÍBLIA CATÓLICA ONLINE, s/d). Disponível em: https://www.bibliacatolica.com.br/biblia-ave-maria/sao-mateus/22/. Acesso em: 19 nov 2019.
} 
de excomunhão. Segue-se com a Unam Sanctam, na qual o Papa adverte o rei quanto às suas responsabilidades, lembrando-o de sua prestação de contas no Juízo.

Outro episódio importante que demonstra esta diferença, entre o poder político e o poder religioso, para que assim se facilite a compreensão daquilo que realmente cabe ao rei fazer e os limites, é quando Santo Ambrósio, Bispo de Milão, proíbe a entrada do Imperador Teodósio na Catedral. O imperador havia, há poucos dias, promovido um massacre após uma rebelião em Tessalônica. Sua entrada seria permitida somente mediante um ato de penitência público. Após realizar sua penitência e de ter se arrependido, é tirado do trono por outro que viria a querer ser deus como imperador. Isso demonstra que o imperador não é Deus, ele pode possuir a espada, mas jamais poderá possuir o báculo. Quando um governante possui o poder do báculo, isso permitirá que ele exija de seus súditos mais tributos, pois concentra num rei dois poderes. Esta separação dos dois poderes é justamente mostrada, pela primeira vez, na civilização judaico-cristã. Assim, sua lei da terra não pode violar a natural (VOEGELIN, 2014, p. 404).

Portanto, parece tarefa difícil, diferenciar quando o pagamento de impostos é justo e injusto.

O imposto, de acordo com Aristóteles (1985, p. 1-10), tem origem na remuneração do rei, este que é elevado a esta condição pela proteção, que oferece aos seus vassalos dos ataques inimigos; enquanto nos tempos de paz, a eles foi dado o poder de punir os criminosos e a autoridade para resolver os litígios. A proteção dos novos súditos costuma ser o denominador comum; ótimo exemplo é o Império Romano ao conquistar Jerusalém, no século IV a.C. Ao povo judeu, é oferecida sua defesa dos outros povos, em troca de parte das riquezas dos súditos, assim como em outros.

De qualquer forma, nenhum rei pode exercer o domínio injusto sobre as posses de seus súditos, isto é, ser proprietário dos bens de seus súditos, sem que seja justa a cobrança. Porém, se for justo, o soberano pode usar dos seus meios de coação para atingir seu fim, contanto que não infrinja a lei natural a qual estão submetidos, como no caso de matar um súdito.

Não obstante, se um soberano infringir o princípio da guerra justa ${ }^{5}$, e em tempos de guerra, aproveitar-se do momento, para tomar presas, de modo a enriquecer; ou aumentar a cobrança de tributos com o mesmo fim, que não seja a defesa dos súditos, ele comete rapina, infringe, como diz Santo Agostinho ${ }^{6}$, a lei natural, portanto, deve restituir os danos causados.

Na verdade, se as posses de todos os súditos estivessem sob a vontade do rei, as ações de Jezebel- esposa de Acab7, quando ela se apropriou da vinha de Nabot, não seriam censuradas tão severamente. Se ela estivesse somente buscando seus próprios direitos, ou aqueles de seu esposo, que certamente era rei, ela estaria reivindicando o que era dela. Se isso fosse verdade,

\footnotetext{
${ }^{5}$ As condições da guerra justa se encontram na Suma Teológica de São Tomás de Aquino (2016). Questão 40: Da Guerra.

${ }^{6}$ Aquino (2016) em Suma Teológica - Questão 66, art.8. Se pode haver rapina sem pecado. São Tomás escreve sobre Santo Agostinho.

${ }^{7}$ A história pode ser encontrada em 1 Reis (21).
} 
Nabot seria acusado de contumácia por injustamente se recusar a pagar sua dívida. (MARIANA, 2011, p. 13)

O confisco das riquezas, quando realizado de forma perversa, ou seja, quando toma injustamente os bens dos súditos, pois toma algo que é de outrem, tem raiz na cobiça humana, assim, por visar frear o enriquecimento do trabalhador ou engrandecer a avareza do soberano às custas dos súditos, um fim perverso, e torna-se, portanto, imoral. A dificuldade está em avaliar, caso a caso, as circunstâncias e o fim do confisco. Caberia, no caso de Zaqueu, o publicano, revisitar sua consciência para ressarcir, quando cometido, os prejuízos causados injustamente.

Como o governo não constitui uma entidade histórica, que teria sua ação realizada por vários membros ao longo do tempo, em termos mais explícitos, quer dizer que tem sua estrutura composta por grupos políticos que o tomam com periodicidade ou não. Assim, não podendo considerá-lo uma estrutura perene. Como o povo trabalha para sustentar seus governantes, sustenta-os por meio de tributos, esses grupos têm como principal poder seu meio de subsistência.

No contexto da desavença moral sobre os impostos, cabe questionar se o governo, em si mesmo, seria (moralmente) bom ou mau. Seria difícil afirmar isso de maneira universal, já que cada governo tem sua formação de maneira particular, e seus dirigentes, como prova a história, não repetem as ações dos antepassados ou seguem uma mesma linha ad eternum. Assim, o governo, apesar de ter se perpetuado por considerável tempo, não pode ser dito eterno, pois uma instituição que tanto cambia seus regimes e grupos políticos no poder, torna-se forçado afirmar um caráter eterno, ou seja, imutável. Entretanto, há ações que o governo realiza, que são constantes. Exemplos disso são a tributação, proteção da vida e da propriedade privada, zelo pela justiça e construção de obras públicas.

Somente é possível analisar o governo quanto à moralidade nessas ações, embora seja falha essa análise, pois se remove o sujeito homem, retirando-se suas intenções com estas ações. Assim, é impossível fazer essa análise em termos gerais e universais, sem considerar um determinado grupo em um determinado espaço e tempo em que realiza essas ações.

Um exemplo da aplicação a uma situação concreta e real é o apresentado pelo padre Juan de Mariana (2011), sobre o governo do imperador César, em seu livro: Sobre o rei a instituição real. Afirma-se que não passava de um roubo, pois não foi domado contra a sua tirania e não extirpou os vícios. Esse caso mostra, justamente que a questão da justiça nos impostos está na tensão entre um governo e os governados, no qual seja justo, e outro, que seja injusto. Juan de Mariana mostra que a justiça nos impostos pode depender da intenção dos atos de um governante, e de maneira alguma, contradiz o próprio Cristo, quando disse que o homem deveria dar a César, aquilo que fosse devido. 


\section{Algumas evidências da Sagrada Escritura sobre o pagamento de impostos}

O pagamento de impostos aparece na Escritura, em diversas partes, entre elas: "Se sacrificarem um boi, ou uma ovelha, darão ao sacerdote a espádua e o peito" ${ }^{\prime 8}$. Outro registro está no livro dos Juízes; os filhos de Israel indagam: “Quem marchará à nossa frente contra os cananeus e será o nosso general na guerra?" . Se alguém marchará pelo povo contra a guerra, este e seus soldados precisam de equipamentos e armamentos, além da prática de exercícios militares constantes, com ou sem risco de guerra. Assim, para que isso fosse possível, era necessário que se pagasse o tributo para bem fazer a preparação para a guerra.

O momento mais importante na história de Israel que envolve o tributo, adjunto do personagem do rei, é quando os anciãos fazem um pedido ao juiz Samuel, que os dê um rei, porque ele já estava velho e seus filhos não haviam seguido o mesmo caminho reto de seu pai. Ele ora ao Senhor Deus. Em resposta, Ele afirma que os anciãos $\mathrm{O}$ rejeitam, e não ao Juiz Samuel. Com esta história, podemos perguntar-nos algumas coisas, considerando que a comunidade era constituída sob Deus: se governo, etimologicamente, vem de "dirigir" do

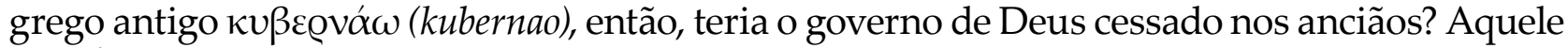
que É responde na linha abaixo da Escritura:

O Senhor disse-lhe: Ouve a voz do povo em tudo o que te disseram. Não é a ti que eles rejeitam, mas a mim, pois já não querem que eu reine sobre eles. Fazem contigo como sempre o têm feito comigo, desde o dia em que os tirei do Egito até o presente: abandonam-me para servir a deuses estranhos. Atende-os, agora; mas declara-lhes solenemente, dando-lhes a conhecer os direitos do rei que reinará sobre eles. ${ }^{10}$

Quais são os direitos do rei? O que o povo deve a ele por suas ações? O soldo do rei. É consequência de sua ação, já que este não poderá participar mais da produção econômica. Ele diz sobre esse novo personagem na história de Israel, que haveria uma espécie de servidão a qual os homens marchariam pelo rei e as mulheres o serviriam ${ }^{11}$. Também, diz aos anciãos que haveriam de pagar o dízimo de seus rebanhos e outros bens ao rei. Assim, estava previsto que haveria a cobrança de impostos, para que o rei mantivesse seus servos. Acrescenta Samuel que eles haveriam de ser escravos do rei.

Nota-se a relação de servidão entre um governante e o governado, essencial, que sem ela não poderia existir. Pressupõe-se assim, o consentimento da autoridade, e, portanto, de seus meios de ação para sê-la enquanto tal. Um consentimento, no caso, maldito. Também em outras passagens na Sagrada Escritura, observa-se a cobrança de impostos para a manutenção do templo. ${ }^{12}$

${ }^{8}$ Deuteronômio $(18,3)$.

${ }^{9}$ Juízes $(1,1)$.

${ }^{10}$ I Samuel (8,4-9).

${ }^{11}$ I Samuel (8,11-17).

122 Crônicas $(24,6)$ e Êxodo (30,12-16). 
Todo rei possui um exército que o legitima, e precisa manter uma condição de vida. Como não pode a todo tempo administrar suas propriedades, pois deve se ocupar do treinamento para combate, terá que contar com parte das riquezas criadas de seus súditos, para sustentar seu exército e a si próprio.

\section{Como a lei natural auxilia na resposta da questão da justiça nos impostos?}

Ora, é verdade que o movimento liberal e democrático dos séculos XVIII e XIX tirou uma boa parte de sua força da doutrina da lei natural e dos direitos inatos e imprescritíveis do indivíduo. Essas ideias, que foram originariamente desenvolvidas pela filosofia antiga e pela teologia judaica, impregnaram o pensamento cristão. (MISES, 2010, p. 101)

Cícero, notável filósofo pagão, define muito bem o que é a lei natural: "A verdadeira lei é a reta razão em harmonia com a natureza (...)todos os povos em todos os tempos serão regidos por uma só lei sempiterna e imutável". (CICERO, 2001, p. 37)

No século VII, Santo Isidoro de Sevilha entendia o direito natural como as leis de procriação e conservação da espécie. Mais tarde, a Escolástica, filosofia medieval cujo expoente é São Tomás, calcado em Santo Isidoro, ensinam que a lei natural é a lei eterna no homem (SOUSA, 1977, p. 5).

Os conceitos de lei natural de Cícero e da escolástica são ressoados pelo anarquista individualista americano, Lyssander Spooner. Para ele, a ciência da justiça é a ciência do meu e do teu. O conceito de direito ou lei natural sofreu deturpações que o desprestigiaram, transformando a lei natural, na lei da razão que desconsidera a realidade natural. As novas leis da razão eram tidas pelos seus novos mestres (SOUSA, 1977) ${ }^{13}$, como feitas pela razão humana e poderiam ser totalmente justificadas por ela.

Depreende-se que se não existir um princípio da justiça (do direito natural), então todo ser humano veio à Terra destituído de direitos, e assim deve permanecer já que esta é sua condição. O princípio de justiça pressupõe direitos inerentes à condição humana: como a vida e propriedade. Além do que, se não houver princípio da justiça não pode haver ciência do governo (SPOONER, 1882), pois de que ato imoral o governo irá protegê-lo? Não existe um princípio, logo não há o certo e errado. Portanto, o governo agirá de forma totalmente arbitrária.

Outrossim, rejeitar a ideia de direito natural é afirmar que todo o direito é determinado exclusivamente por legisladores. Essa ideia implica que toda e qualquer tributação, determinada pelos governantes, seria justa. Cícero corrobora essa visão, afirmando que se um poder conseguisse alterar a natureza das coisas, qual seria a razão para que ele não transformasse o mal em bem ou a injúria em direito (CÍCERO, 2001, p. 16). Essa distinção é a mesma feita por Aristóteles, ao distinguir o justo por lei e justo por natureza (ARISTÓTELES, 1985, p. 38).

${ }^{13} \mathrm{O}$ autor se refere a Grócio, Puffendorf, Rousseau e Kant. 
Como nenhum homem pode fugir à lei natural, pois estão todos sujeitos a ela, assim o mesmo se aplica aos príncipes e governantes; se a violassem, estariam negando a natureza humana deles próprios e de seus súditos. Pelo fato de a lei ser um preceito racional, deve se conformar à reta razão, ao direito natural. Porém, é um preceito racional para o bem comum, logo, deve também conformar-se ao interesse social. Contudo, sem que prescinda da ideia de direito natural, uma vez que, fora do direito natural, não existe nenhum critério objetivo que possa ser imposto ao legislador.

Outra corrente de pensamento, os contratualistas, calcados na teoria do contrato social de Hobbes, poderiam perguntar: "e se o governo foi fruto do contrato arbitrário entre partes? Se for uma convenção?". Esta pergunta pressupõe a inexistência de uma moral, ou no mínimo, um tipo peculiar. Este tipo, que se aplica apenas ao contrato, e não às outras coisas. Se então este tipo de moral existe, ela deve ser universal, de modo a ser verdadeira, e, portanto, se aplica a todos os casos. Logicamente, a moral seria: é certo manter o contrato e errado quebrá-lo. Assim, se o contrato, mesmo que seja indevido, isto é, injusto, não pode ser violado, se firmado.

$\mathrm{O}$ "contrato", quando feito dessa maneira, e visando o enriquecimento do soberano, viola a lei natural, logo, infringe os direitos dos súditos que jurou proteger. Logo, se o soberano tem o dever de assegurar a vida e a propriedade dos súditos, então cobrar tributos sem necessidade, seria violar a propriedade de seus súditos. Portanto, o contrato que viole a lei natural, seja em seu início ou durante sua vigência, está sujeito ao exame da razão, e não é indissolúvel.

\section{Visão Escolástica e o conflito sobre a justiça no imposto}

O pensamento de São Tomás foi grande influência para os escolásticos tardios e motor para suas ideias sobre o imposto. Para Domingo de Soto, o mais proeminente discípulo daquele que é conhecido como o pai da escolástica hispânica (CHAFUEN, 2009, p. 106), afirma, assim como outros escolásticos contemporâneos, que os impostos têm como fim a proteção da propriedade privada. Isso implica que parte dela seja apropriada, o que restringe seu uso. "Seus efeitos benéficos eram a paz, a concórdia, a ordem e o desenvolvimento" (CHAFUEN, 2009, p. 106).

Para os escolásticos, o governo tem origem para a proteção da propriedade. Por isso, a lei de imposto deve cumprir os requisitos de toda lei: derivar da lei natural, pois como diz Agostinho: "parece que aquilo que não é justo, não pode ser lei". Assim, nem todo imposto é justo. Além do que, a autoridade deve ser legítima, ou seja, o governo deve ter o consentimento do povo. A medida justa da tributação é a moderação na cobrança (CHAFUEN, 2009, p. 152).

Entretanto, outro autor da Idade Média, Sylvestre de Priero, "apontou que as leis que concedem aos príncipes, os tesouros que os outros encontram, mesmo que sejam nos campos e terras dele, são contra o direito natural e civil" (s/d apud CHAFUEN, 2009, p. 106). Para outro autor, Paludano, os príncipes, por costume, tinham propriedade sobre qualquer tesouro encontrado "em suas terras". Domingo de Soto afirma que "esse costume não ocorreu em nenhuma sociedade bem organizada e que se porventura ocorreu foi por causa da força ou seja, a imposição dos agentes no reinado - que é contra o direito natural" (2009, p. 107 [traduzido pelo autor]). 
Juan de Mariana, outro escolástico tardio, apelidado por Rothbard de o extremista (1995, p. 117), apresenta peculiar visão sobre as atividades do governo. De acordo com Mariana (1598), os homens no começo seguiam a lei natural, sem a existência de uma lei positiva, ou seja, de uma lei colocada pela autoridade competente com fim da ordenação racional para o bem comum (DE AQUINO, 2016, p.585). Contudo, com a violência do homem, pilhagens e roubos, a vida e a propriedade passaram a ser desrespeitadas. E assim, se forma o Estado para proteger os homens. Mariana afirma que houve impérios que se formaram, a partir da invasão e conquista de territórios, enquanto outros pelo consenso dos homens (LAURES, 1928, p. 32). Exemplos de impérios, que se formaram a partir da invasão, foram os mongóis, e aqueles oriundos do consenso entre os homens foram os ingleses que se unificaram sob Etelstano do condado de Wessex ${ }^{14}$. Também se afirma que "impérios fundados na violência e injustiça jamais poderão ser legítimos, apesar da legislação subsequente" (LAURES, 1928, p. 20-25).

Se tomarmos o pensamento de um de seus contemporâneos, Francisco Suarez (ano) ${ }^{15}$, este justifica a existência do Estado com dois argumentos: "(1) nenhuma família é autossuficiente; (2) se houvesse divisão entre várias famílias, não haveria paz" (2009, p. 1-3).

Essa tensão, que os escolásticos apresentam sobre o imposto, se seria ou não justa sua cobrança em determinados casos - estando ou não contidas na lei moral, é retratada, na época, na bula Papal Coena Domini (LAURES, 1928, p. 125), na qual declara a excomunhão de um príncipe, que intentasse impor impostos sem o consentimento do povo.

Hoppe (2014) faz semelhante análise, sobre a justiça no imposto na Idade Média, quando avalia a capacidade dos senhores feudais de taxarem seu povo, que era condicionada ao consentimento: "Senhores feudais e reis podiam "cobrar impostos" mediante o consenso dos pagadores, todo homem livre tinha tanto de um soberano, em outras palavras, tinha a decisão final, assim como o senhor feudal tinha no seu caso. Sem consentimento, impostos eram considerados confisco, isto é, expropriação injusta (p. 32 [traduzido pelo autor])."

Juan de Mariana, ao explicar as atividades do governo, analogamente, aos monopólios de sal e loterias, dizendo que monopólios não se diferenciam em substância de impostos, ou seja, ambos coagem; assim, precisam do consentimento do povo.

Portanto, o problema do consentimento, para a cobrança de impostos, parece permear a relação tributária entre os que cobram e os que são cobrados. Denotando um conflito entre as partes, que se perdurou em diferentes conjunturas históricas e parece que irá se perdurar por muito tempo, ou até que haja a abolição do Estado, tão querida por Rothbard.

Sobre a tradição tomista-aristotélica, Rothbard argumenta assim: parece que a tradição tem grande defeito em sua concepção da lei natural ao conceber o Estado como centro da ação virtuosa, uma vez que na concepção política dos gregos, a virtude conduzia à política

\footnotetext{
${ }^{14} \mathrm{O}$ documento histórico relata que a concorrência entre pequenos reinos foi, ao longo dos anos, unificando-se sob o reinado de Etelstano, até ele tornar-se rei do Sul da Inglaterra, tendo que defender o povo de diversas invasões Vikings durante o reinado. (LAURES, 1928, p. 20-25).

${ }^{15}$ Considerado como um dos pais do direito internacional, com sua obra De Iure Gentium (Direito dos Povos (1612)) e De Legibus (Da Lei (1603)).
} 
(2010, p. 75). Ele afirma que John Locke teria sido o autor de uma teoria individualista, em lugar da estatista.

Mas, em contrário, diz Locke algo muito semelhante a Agostinho De Hipona ${ }^{16}$ :

O agressor que se coloca em estado de guerra com outro homem, injustamente invadindo o direito deste, jamais extrairá de uma guerra injusta nenhum direito sobre sua conquista. Facilmente concordarão com isso todos os homens que não acham que os ladrões e os piratas têm um direito de soberania sobre quem quer que seja que tenham dominado pela força; ou que os homens sejam obrigados por promessas que o uso ilegal da força lhes extorquiu. Se um ladrão invadir minha casa e, com um punhal em minha garganta, me obrigar a escrever um documento cedendo-lhe os meus bens, isto lhe dá qualquer direito? É justamente um direito deste gênero que possui o conquistador injusto que força a minha submissão com o poder da espada. A injúria e o crime são iguais, sejam eles cometidos por uma cabeça coroada ou por algum pequeno vilão. (LOCKE, 2006, p. 84)

Por fim, um raciocínio que auxilia na compreensão das transformações da pólis, anterior à Idade Moderna, para entender melhor o que ocorreu no tocante à tributação, é a divisão do trabalho que sucede o acúmulo de riquezas. Pode-se pensar que, se os homens querem manter suas propriedades, devem estar dotados dos meios para bem fazê-la, podem cada um deles ter uma espada na bainha, e assim, devem vigiar sua família e suas propriedades, ou podem contar com algumas pessoas, geralmente mais agressivas e mais fortes do que o normal, para defendê-los. Nisso, desenrola-se, com o tempo, que cada um especializa-se naquilo que faz melhor. Decorrência disso, é que o povo, no exemplo do grupo de pessoas, que trabalha para sustentar aqueles que irão defendê-los, uma vez que o trabalho dos "defensores" não mais se tratará de cultivar o trigo e vigiar as plantações (o que faziam anteriormente à divisão), mas somente de vigiá-los. Logo, nada produzirão os defensores, assim, será preciso que alguém produza pelo defensor, o que constitui o pagamento de um soldo. Nisso, intercorre que os "defensores" busquem expandir a coleta de suas cifras além do necessário e com outra finalidade, que não seja seu sustento, mas um confisco tirânico, para seus interesses pessoais - isto é, uma rapina oposta à justiça. Consequência não nobre disso pode ser a semeação de corrupção e injustiças, estas que se iniciaram com o ato de exigir mais daqueles que cultivam a terra.

\section{Considerações dos pensadores da tradição liberal sobre a questão}

O liberalismo está longe de questionar a necessidade da máquina do Estado, do sistema jurídico e do governo. Trata-se de grave incompreensão associá-lo, de algum modo, à ideia de anarquismo, porque, para o liberal, o Estado constitui uma necessidade absoluta, uma vez que lhe cabem as mais importantes tarefas: a proteção não apenas da propriedade privada, mas também da paz, pois, em sua ausência, os benefícios da propriedade privada não podem ser colhidos. (MISES, 2010, p. 66)

\footnotetext{
${ }^{16}$ Agostinho afirma que, apartada à justiça, os reinos não são nada mais que uma quadrilha de ladrões, ao contar a história de um pirata que foi preso e questionado por Alexandre Magno. (DE HIPONA, 1996, p. 383)
} 
A tradição liberal, para seu tempo, introduz no campo das ideias uma ruptura, uma vez que coloca como o maior valor político a liberdade, impondo, ao soberano, restrições e limites para suas ações, visto que muitos príncipes eram donos de toda a terra em seu reino, com os súditos não tendo nenhuma propriedade sobre a terra. A corrente clássica, composta por pensadores como Locke, Hobbes, Smith e Ricardo, tem suas concepções sobre a moralidade dos impostos, baseada no consentimento dos governados.

John Locke, o fértil genitor das ideias liberais, afirma que o consentimento é a origem da autoridade legítima. Sua visão difere do contemporâneo Hobbes, já que, para Locke (MERQUIOR, 1991, p. 45), o homem, ao constituir um governo não alienaria todas suas liberdades, pois seus direitos naturais, entregues pelo Criador ao homem, não seriam anulados. Assim, mesmo que não fossem promulgados na lei humana ou até desrespeitados pela mesma, não deixariam de participar da lei natural, e o respeito a esses condicionaria o consentimento.

A principal reinvindicação do direito natural da propriedade e a tentativa de controlar o poder do soberano são os pontos nos quais reside a questão moral dos impostos para os liberais clássicos, uma vez que os impostos são cobrados sobre as propriedades dos súditos. Assim, o poder ordenador não deve impor tributos sem o consentimento do povo, pois, dessa forma, incorre na invasão (LOCKE, 2006, p. 74) da lei de propriedade. Ricardo afirma: "na realidade, podemos considerar esse mal como o inconveniente inevitável de todo o imposto arrecadado e gasto pelo Estado. Cada novo imposto se transforma em um novo encargo para a produção e aumenta o preço natural dos produtos" (RICARDO, 1982, p. 135). Com o avanço desse governo mal ordenado sobre a propriedade, torna-se legal a resistência do povo contra o tirano, que atente contra suas vidas e propriedades.

Como a tradição liberal vê a necessidade do Estado, por consequência, a cobrança de impostos se faz necessária, para que o Estado tenha os meios para cumprir seu fim: colher os benefícios de sua propriedade em paz.

"Por isso, o objetivo capital e principal da união dos homens em comunidades sociais e de sua submissão a governos é a preservação de sua propriedade" (LOCKE, 2006, p. 69).

John Locke, ao passo que faz esta declaração, adverte, sobre o confisco das propriedades privadas. Afirma que a "comunidade é investida de salvaguardar contra tentativas perversas de quem quer que seja, mesmo dos legisladores, de desenvolver projetos contra as liberdades e propriedades dos súditos" (LOCKE, 2006, p. 76).

Adam Smith, o escocês de Kirkcaldy, ao afirmar os deveres do soberano, vai além da defesa da vida e propriedade, e elenca três deveres: defender a sociedade da violência e invasão de outras sociedades independentes; proteger tanto quanto possível todo membro da sociedade da injustiça ou opressão de qualquer outro de seus membros; erigir e sustentar as instituições públicas e obras públicas (SMITH, 2017, p. 346-347).

Embora a tradição considere os impostos morais condicionados ao consentimento, isso não impede que haja impostos injustos. Exemplo disso, é o imposto sobre herança - este que incide da transferência de propriedade dos mortos para os vivos - que é antieconômico, porque geralmente apenas aumenta os rendimentos do monarca, que mantém trabalhadores improdutivos (SMITH, 2017, p. 346-347). 
David Ricardo demonstra que os impostos são pagos pelo capital e rendimento dos homens num país. Seu aumento reduz os fundos destinados ao consumo produtivo (RICARDO, 1996, p. 109). Thomas Hobbes (2014, p. 120) coloca que o soberano tem o direito de recolher os impostos para pagar seus soldados e administrar a justiça, porque a alienação deste poder torna o comando da milícia algo em vão (2014, p. 154). Ele também cita o Santo Apóstolo Paulo: “Todo homem esteja sujeito aos poderes superiores: porque não há poder que não venha de Deus"17.

Um bom exemplo, de como alguns mal interpretaram essa sentença, assumindo serem eles próprios o deus, são James I e Charles I da Inglaterra, que acreditavam que detinham o poder por direito divino e que a soberania residia na pessoa do rei ${ }^{18}$; e com isso, os conflitos se iniciaram quando James I tentou impor mais impostos. Porém, ele sabia que não podia fazer isso diretamente, já que não podia criar novos impostos sem a autorização do parlamento - que se expressa na célebre frase "No Taxation without Representation". Assim, ele tenta aumentar o recolhimento de tributos pelo aumento do território que vigora o tributo ${ }^{19}$. Alguns nobres se revoltam contra o rei. Por isso, em represália, ele tentou prender cinco membros do parlamento, mas as tropas do rei são repelidas pelas tropas do parlamento ${ }^{20}$. Desde então, o monarca não pode entrar na Câmara dos Comuns. Todos os anos, isso é lembrado na abertura do Parlamento inglês.

O fim do conflito ocorre quando a Suprema Corte da Inglaterra emite um documento, que diz que o poder do rei advinha de seus direitos da terra, separando-o do direito divino, separando o poder político do poder religioso. Vale mencionar o episódio em que Cnut, conquistador da Inglaterra, de frente ao mar e de costas aos súditos, diz ao mar: "Eu sou o rei de todos os ingleses e ordeno que a maré pare de subir". Obviamente, a maré não parou, e por isso, ele virou-se aos súditos e disse: "há leis que nem o rei da Inglaterra pode mudar" (BENNET, 1993).

"Pois os impostos que são cobrados do povo pelo soberano nada mais são do que os soldos devidos àqueles que seguram a espada pública para defender os particulares no exercício de várias atividades e profissões" (HOBBES, 2014, p. 292).

Em oposição a essas ideias, Hoppe, argumenta: “há grave erro, na teoria liberal do governo, ao considerar a instituição do governo como coerente com os princípios liberais, esses que são, acima de tudo, uma doutrina moral baseada nos estoicos e escolásticos tardios" (HOPPE, 2014, p. 260), sendo o erro que a condição moral do governo derivasse do problema humano da segurança, além do que seria ilusória a restrição do poder governamental na realidade.

\footnotetext{
${ }^{17}$ Trecho visto na Bíblia Sagrada, na Carta de São Paulo aos Romanos $(13,1)$.

${ }^{18}$ Esse pensamento teve influência das Teorias do Direito Divino, do bispo francês Jacques Bosset, culminando, assim, em sua obra póstuma: A Política Tirada das Sagradas Escrituras, em 1708. O jurista Jean Bodin foi outro que se deve destacar por sua obra, Six livres de la République, em 1576.

${ }^{19} \mathrm{O}$ tributo é chamado de Ship Money. O nobre mais conhecido, que reconheceu e denunciou isso, foi John Hambdem. Há um livro, que relata esse momento histórico, cujo nome é The Tryal of John Hambdem.

${ }^{20}$ Esse fato ocorreu em agosto de 1642. (BBC, s/d)
} 
Mas, em contrário ao seu argumento, a teoria liberal encontra o limite do governo nos próprios princípios, a lei natural, sendo ela o limitante para o poder governamental, sendo o melhor exemplo de que sua usurpação é tida como as causas razoáveis para o rompimento dos laços com o governo.

A independência dos EUA, expressa na Declaração de Independência, é um ótimo exemplo de como esses princípios foram a medida para sua emancipação e constituíem o próprio governo, com leis que evitassem o surgimento de uma nova tirania.

Entretanto, aí está precisamente a distinção, uma vez que um governo só pode ser bom se estiver fundado na justiça, portanto, que respeite a lei natural. Mas a argumentação de Hoppe tem muita razão quanto a esperança que muitas pessoas tem na limitação do governo per se, visto que o mundo atual é composto de governos que não governam segundo a justiça, mas segundo a injustiça, os quais, em vez de promulgar leis humanas condizentes à lei natural, buscam decretar sua própria vontade arbitrária ou a vontade do povo e juízes, contra a reta razão.

Os liberais clássicos aceitam os impostos, contanto que sigam o fim para que foram criados: a defesa dos súditos e de suas propriedades; e a justiça. Portanto, o Estado, isto é, o soberano e seus membros, segundo esses pensadores, não cometem injustiça, ainda mais quando ele deve proteger os súditos da injustiça, logo, não praticam imoralidade.

Note-se que os impostos, do qual se escreve, podem ser cobrados em última instância sobre três fontes: renda, lucro e salário (SMITH, 2017, p. 548).

A pergunta que se faz é, se o consentimento considera uma quantidade. Afinal, se sim, poder-se-ia determinar a moralidade do imposto delimitando uma quantidade ou percentual específico, a qual superada, torná-lo-ia imoral; ou se o consentimento é relativo ao tipo de imposto cobrado. O que parece é que, a regra para o limite é a prudência e a moderação.

\section{A questão na contemporaneidade}

A contemporaneidade torna a análise ainda mais difícil para a delimitação das fronteiras do Estado. Faz-se necessário lembrar que o poder do soberano aumentou, seja pelo avanço tecnológico, como pelo aumento de sua extensão territorial e controle da vida cotidiana dos súditos. Outrossim, ocorreu o aumento da atuação do Estado pela intervenção em um maior número de mercados, assim, tornando-se, em muitos países, um dos principais agentes econômicos ${ }^{21}$.

A contribuição da contemporaneidade para a questão se dá porque ela é o plano de evidências, no qual se deve, primeiro, confrontar o pensamento dos autores acima, segundo, apresentar os casos nos quais seria injusto e considerado roubo, e terceiro, tempo no qual o autor se insere na história.

\footnotetext{
${ }^{21}$ No Brasil, segundo o Banco Interamericano de Desenvolvimento, o Estado gasta o equivalente a $42 \%$ do PIB. (G1, 2019. Disponível em: https://g1.globo.com/economia/noticia/2019/05/07/estudo-do-bid-diz-que-brasil-gastamuito-e-gasta-mal-ineficiencias-somam-us-68-billoes-por-ano.ghtml. Acesso em: 28 set 2019).
} 
A presente seção se propõe a expor a questão da justiça nos impostos no Brasil; as declarações dos Papas, no século XX, sobre a matéria, e o pensamento de autores austríacos, como Hoppe, Rothbard, Mises e Hayek, sobre tal questão, considerando o maior poder que os regimes totalitários conquistaram no século XX.

Ron Paul, um congressista libertário norte americano, é um bom ponto de partida para compreender a moralidade e os impostos na contemporaneidade, devido ao trabalho que exerce na política, baseado no pensamento da Escola Austríaca. Ele afirma:

Não obstante os impostos terem começado pequenos, a natureza humana funciona de tal forma que os políticos e os beneficiários da generosidade do governo, agiram de forma que os impostos subissem inexoravelmente. Além disso, conquanto a maioria pense nos danos da excessiva tributação da renda apenas, há muitos outros impostos igualmente abusivos: sobre as vendas, sobre a propriedade, para escolas, impostos distritais, municipais, específicos e sobre a herança: todas as atividades produtivas pagam seu imposto. (PAUL, 2013, p. 149)

Hoje, o número existente de impostos já denota certa distorção em sua justiça. Ademais, o valor cobrado (alíquotas) é alto. O exemplo mais icônico de que esses impostos esmagam e assolam o cidadão, é a migração de grandes fortunas de países com alta carga tributária (França e Alemanha, até 1997) para países com menor carga tributária (EUA e Reino Unido, antes do Brexit). Não obstante, entre os impostos referidos, aquele, contra grandes fortunas, seria visto por Smith como antieconômico, por punir quem muito produz, além de ser discricionário.

Os impostos têm sua cobrança aumentada, geralmente, em três situações: construção de obras públicas, financiamento de guerras, falsificação da moeda - adulterando-a (MALOONEY, 2013); consistindo um imposto, o imposto por inflação, uma vez que os impostos são cobrados de forma nominal, e não real. Em todas elas, a poupança presente dos homens, como disse Margareth Thatcher"22, é "emprestada" aos governos, para realizarem suas obras.

Nota-se que, no século XXI, perdeu-se a noção de que o imposto é a expropriação de parte da riqueza advinda da atividade econômica, ou seja, do trabalho do homem. As palavras "public money" são um bom exemplo disso. Considera-se como se o dinheiro do governo não tivesse origem no dinheiro de cada homem.

Contudo, isso não é uma exceção à contemporaneidade, essa mudança de percepção e vocabulário remonta ao século XII, no qual demonstra que a noção de rei e súditos fora alterandose. Felipe Augusto, passou a chamar-se "rei da França", em vez do "rei dos francos". Na mesma época, Ricardo I intitula-se "rei da Inglaterra", não mais "rei dos ingleses (MORTIMER, 2018). Isso acentua a ideia de que os reis governam todas as pessoas em seus domínios, inclusive os estrangeiros, não apenas seus seguidores. Mas isso implicava também na ideia de que devia proteger todos (MORTIMER, 2018).

Diversas mudanças ocorreram na relação entre reis e súditos. Cada vez mais na história, o rei adquiriu mais poderes e menos limitações ao seu poder. Enquanto os súditos, progressivamente, foram cada vez mais taxados. Provavelmente, um homem da Antiguidade ou Idade Média, que visse o quanto é taxado no século XXI, ficaria assustado e perguntaria se todos tornaram-

${ }^{22}$ Dito na Conferência do Partido Conservador, em 1983. 
se funcionários do Estado. Em seguida, perguntar-se-ia se o soberano cumpre seu papel de proteção das vidas, propriedades dos súditos, a administração da justiça e construção de obras públicas. Assim, ao saber a resposta, se fosse de origem portuguesa, desejaria ardentemente pagar O Quinto à coroa, que era pago no período do Império no Brasil ${ }^{23}$.

No Brasil, aparentemente não, pois quase nada oferecido pelo Estado, parece ser bom. Uma estatística do Instituto Brasileiro de Planejamento e Tributação apresenta a realidade de quase servidão ao Estado, ao informar que o brasileiro trabalha mais de 145 dias no ano, para pagar impostos (UOL, 2019). É evidente pensar que, se trabalha-se todo esse tempo para o governo, o retorno deve ser no mínimo valioso, entretanto, às vezes, nem há sinal de retorno. Uma possível pergunta frente a isso seria: o que aconteceu com o dinheiro? Em decorrência das investigações da Operação Lava Jato ${ }^{24}$, o povo suspeita que foi roubado ou mal administrado. Não pode ter sumido, mas pode ter sido muito mal direcionado ao povo e bem direcionado aos bolsos de certos grupos, que se apropriam do Estado; o que não é novidade na história do Estado. O que parece destoar é o quanto o povo torna-se escravo do governo e deve quase metade de sua propriedade, em termos grosseiros, ao Estado. Não parece, no caso, ser moral.

Além disso, foi possível notar, nos últimos anos, que o Estado brasileiro foi aparelhado, ou seja, tomado pelos grupos políticos, que se destinavam a sugar os recursos arrecadados do Estado, para financiarem suas ações. Durante o período, a partir dos anos 2000, desse governo, o fisco do Estado foi saqueado por inúmeras formas: licitações inadequadas, crédito subsidiado às empresas conhecidas, fomento às políticas "assistencialistas de caridade compulsória", relações de corrupção com incorporadoras e empresas do Estado, como Petrobras e BNDES.

Essa ação de grupos se aparelharem no Estado não é novidade, uma vez que o Estado, além de poder ser formado pela união dos homens, também se funda pela guerra e conquista. Um exemplo de formação, a partir da guerra, é o Estado português, com o rei Afonso Henrique. Raymundo Faoro auxilia na compreensão da natureza da atividade do Estado brasileiro, com base no português.

Guerra, ascendência do rei com a rede de seus agentes cobrindo o país, controlando-o e dirigindo-o, domesticação sem aniquilamento da nobreza - são os traços que imprimem o caráter à sociedade nascente (...). A propriedade do rei - suas terras e seus tesouros - se confunde nos seus aspectos público e particular. Rendas e despesas se aplicam, sem discriminação normativa prévia, nos gastos de família ou em obras e serviços de utilidade geral. O rei, na verdade, era o senhor de tudo - tudo hauria dele a legitimidade para existir - , como expressão de sua autoridade incontestável, bebida vorazmente da tradição visigótica e do sistema militar. Discernir e especificar a fonte dos ingressos da realeza será trabalho de revelação da própria estrutura econômica do reino. (FAORO, 2001, p. 19)

O estamento político, uma comunidade em cada um age com base em seu grupo, apresentase na obra:

\footnotetext{
${ }^{23}$ Muito menos do que se paga hoje.

${ }^{24}$ Conjunto de operações da Polícia Federal, em conjunto com o Ministério Público, para a investigação do esquema de corrupção de lavagem de dinheiro, que envolveu políticos, partidos políticos, funcionários públicos, e empresários e diretores de empresas.
} 
O estamento supõe distância social e se esforça pela conquista de vantagens materiais e espirituais exclusivas. O fechamento da comunidade leva à apropriação de oportunidades econômicas, que desembocam, no ponto extremo, nos monopólios de atividades lucrativas e de cargos públicos (...). Significa esta realidade - o Estado patrimonial de estamento - que a forma de domínio, ao contrário da dinâmica da sociedade de classes, se projeta de cima para baixo. (FAORO, 2001, p. 59)

Colocando a discussão mais próxima do século XX, o novo conquistador César, com a foice colocada na bainha, executava uma das medidas proposta por Karl Marx: a expropriação da propriedade latifundiária e emprego da renda em proveito de Estado (MARX, 2010, p. 58). Em outras palavras, o roubo. O Estado moderno, como se pode observar na recente história do Brasil e de outros países como a China e Rússia, evidencia que a política de tais países foi pautada pelo plano de ação comunista ${ }^{25}$. Uma das ideias de Marx e Engels que é importante ser exposta no presente trabalho, de modo a mostrar qual o pensamento basilar para as ações que tão largamente abrangeram boa parte das políticas do governo quanto à propriedade e a tributação, é moral segundo esses.

Em que sentido negamos a ética e a moral? Negamo-las no sentido em que são proclamados pela burguesia, que as deduz dos mandamentos de Deus. Nós, evidentemente, afirmamos não crer em Deus. Sabemos perfeitamente bem que o clero, os proprietários de terras e a burguesia afirmam falar em nome de Deus para proteger seus próprios direitos como exploradores. Negamos toda moralidade baseada em conceitos sobre-humanos ou exteriores às classes. Afirmamos que isso é um engodo, uma trapaça, um obscurecimento das mentes dos trabalhadores e camponeses em proveito dos proprietários de terra e dos capitalistas. (LENIN, 2001, p. 47-48)

$\mathrm{O}$ agente do FBI, Cleon Skousen, autor do livro O Comunista Exposto e investigador do tema, afirma sobre a concepção moral dos marxistas: "Creêm que mandamentos como não furtarás e não cobiçarás são exemplos da busca da classe dominante, pela imposição do respeito à propriedade às massas exploradas" (SKOUSEN, 2018, p. 93). Dessas duas citações, depreende-se, primeiro, que o indivíduo, em tal regime, não mais está resguardado pelas leis humanas de seus direitos naturais; e segundo, que ao participar do regime comunista, por não poder possuir nada, logo, o homem não é mais dono do fruto do próprio trabalho, portanto, estabelece a mais completa servidão ao Estado.

Sobre isso, Hayek (2010, p. 92) afirma que o Estado se transformou em uma instituição "moral", assim, impõe sobre os súditos suas ideias sobre a moral, sejam elas corretas ou não. Portanto, tanto o Estado totalitário Nazista, como outro poderia ser considerado moral. Com essa transformação, o Estado, negando a moral, torna-se mais suscetível à ação de homens inescrupulosos, que tendem em suas ações à progressão do totalitarismo (HAYEK, 2010, p. 140).

Nesse plano, no qual está contido a violação da lei natural, a moral burguesa é substituída por uma moral coletivista da igualdade (HAYEK, 2010, p. 154), através do dirigismo econômico nos mercados. Em suma, por um Estado que sobrepassa seus limites da defesa da propriedade e justiça para o campo empresarial, constituindo empresas públicas para ofertar bens e

\footnotetext{
${ }^{25}$ Não me detenho em me estender na explicação do fenômeno. Apenas coloco o plano, em sua maneira mais abrangente: a derrubada do regime capitalista e a implantação da ditadura do proletariado.
} 
serviços. Os limites frágeis podem se expandir até o total coletivismo e a expropriação quase total da propriedade.

Uma analogia útil, para melhor compreender o poder do Estado, é a seguinte: uma empresa tem seu poder, ou seja, sua capacidade de ação, derivada em parte do montante que ganha no mercado (sua receita), podendo assim destiná-lo da forma que preferir, conforme o desejo dos dirigentes ou sócios. De maneira análoga, pode o Estado tudo, em potência. Assim, o tributo, que é o recurso que tem a receber do povo, equivalente à renda do Estado, é um poder, pois possibilita a ação do Estado. Sem o tributo, o Estado não tem como agir, assim, um dos elementos do poder do Estado reside nisso, adjunto do poder da espada, que utiliza para coagir quem atenta, contra sua ordem.

Nesse contexto, a Escola Austríaca é a corrente de pensamento, que refutou intelectualmente a teoria socialista e denunciou os problemas e o avanço do estatismo, com mais notoriedade.

Mises afirma sobre o meio de poder ao Estado: "A tributação se torna a arma favorita do intervencionismo. As leis de tributação não buscam mais exclusivamente ou predominantemente o aumento das receitas do Estado; elas têm intenção de servir a outros propósitos além dos requisitos fiscais" (1959, p. 494 [traduzido pelo autor]).

Rothbard (2013, p. 103-105), sobre esse ponto, afirma:

Os altos níveis do imposto de renda significam que todos nós trabalhamos durante boa parte do ano - muitos meses - de graça para o Tio Sam antes de recebermos a permissão de usufruir de nossa renda no mercado. Parte da essência da escravidão é, afinal de contas, forçar alguém a trabalhar para outra pessoa em troca de pouco ou nenhum pagamento.

Essa situação de servidão pelos impostos causa grande desconforto na vida das pessoas, pois elas percebem que sua propriedade, de fato, não as pertence. O professor Soto compara a queda do Império Romano, com o "Estado de Bem-Estar Social" ${ }^{26}$ moderno, no qual alguns grupos têm seus benefícios, custeados por todos os pagadores de impostos. Quase como se o lema de sua política fosse o romano: "Panem et circense", já que os benefícios visavam agradar o povo, pela repartição do pão entre os pobres. Jesús Huerta De Soto indaga quem iria trabalhar para produzir pão, se estava sendo dado sem cobrar um preço pelo bem. O pão da política romana, fora provido com a adulteração da moeda, ou seja, mais uma forma de cobrar impostos de maneira indireta (2019).

Se o imposto se torna também uma medida para introduzir o pater omnipotens Estado, então, expropriar riqueza é um meio para que o Estado possa concentrá-la, aumentando o poder de seus agentes. Com isso, o aumento da participação do governo na economia, como já indiciado no texto, é uma consequência natural. Um Estado de bem-estar social, para cumprir com suas novas responsabilidades de "caridade aos pobres", deve aumentar seus gastos e só pode fazer isto aumentando os impostos. ${ }^{27}$

${ }^{26} \mathrm{O}$ Estado, que promove o bem-estar econômico e social dos cidadãos, de modo que o Estado "custeia" seus benefícios, tornando o Estado como provedor à custa de todo o povo. Um bom exemplo disso é a política de renda governamental.

${ }^{27}$ Ceteris Paribus. 
Se o Estado, em prol desta sublime caridade, cria um programa, batizado como: Pater auxilium, será consequência disso, o aumento de impostos, de modo a efetivá-lo, assim, a carteira do cidadão é comprimida e diminui.

O atual projeto socialista de escravidão humana, para um dos Santos Padres, ergue-se com base na cobiça ${ }^{28}$. Assim, é fácil concluir que o próximo passo é o furto da propriedade pelo Estado, seja de maneira progressiva e paulatina, ou descarada. Este tipo de intervenção estatal em toda a vida do governado, como proferido pelo seu sucessor, o Papa São João Paulo II (1991, p. 854), irresponsabiliza a sociedade, o criador do Pater auxilium provoca perda das energias humanas e o aumento exagerado do setor estatal. O Santo Padre afirma que este domínio tem as seguintes características: "o aumento exagerado do sector estatal, dominando mais por lógicas burocráticas do que pela preocupação de servir os usuários com um acréscimo enorme das despesas". Nota-se que alguém não se contentou com seu soldo.

Também é importante atentar para a denúncia dos três regimes tirânicos, feita pelos Santos Padres, ao longo do século XX, em suas encíclicas ${ }^{29}$. Afirmando, nelas, o desrespeito à lei natural, e que disso, poderia decorrer a divinização do Estado e idolatria dos governantes. Pode-se fazer uma analogia dos ocorridos no século XX, com o tempo histórico do absolutismo europeu quanto à divinização do Estado, no qual ambos colocam o soberano acima de seus poderes devidos, com a diferença que, nos regimes totalitários modernos, em vez de ser justificado pelo direito divino como no absolutismo europeu, dá-se pela crença na capacidade do Estado de prover tudo a todos (onipotência), em melhor saber o desejo do povo (onisciência), e sua onipresença por ser vista como solução para todos os problemas.

Recordando o ramalhete de "Dar a César o que é de César, e a Deus o que é de Deus"; identifica-se que, dado o fim que se almeja por meio dele, sua cobrança parece não ser indevida. "Visto que o Estado, ao contrário de outros indivíduos e instituições da sociedade, obtém sua receita, não por trocas livremente firmadas, mas por meio de um sistema de coerção unilateral chamado de 'tributação'" (ROTHBARD, 2012, p. 22).

Como o Estado deve servir aos seus súditos; o intuito de aumentar o poder do Estado é no processo de enriquecer seus membros por meio dos impostos. E se o Estado se torna mais poderoso que a sociedade, ele se encaixa na definição do totalitarismo, assim o homem ao parasitar o Estado, parasita a sociedade. "Tudo no Estado, nada contra o Estado, e nada fora do Estado" ${ }^{\prime \prime 30}$ é o ramalhete destes homens.

Se o Estado não serve aos seus súditos, mas seus súditos ao Estado, inverte-se a razão de existência do Estado. Assim como o sábado foi criado para o homem, e não o homem para o sábado $^{31}$, o Estado foi criado para o homem e não o homem para o Estado.

\footnotetext{
${ }^{28}$ Afirma Leão XIII, na Encíclica Rerum Novarum (1891).

${ }^{29} \mathrm{O}$ nazismo, na encíclica Mit Brennender Sorge ("Com Ardente Preocupação) de Pio XI; o fascismo italiano, na encíclica Non Abbiamo Bisogno ("Nós Não Precisamos") de Pio XI; o comunismo ateu, na encíclica Divini Redemptoris ("Divino Redentor"), de Pio XI.

${ }^{30}$ Benito Mussolini (1932).

${ }^{31}$ Evangelho de São Marcos (2,27).
} 


\section{Afinal, há justiça no imposto?}

Como se pode já perceber pela argumentação do texto, há uma justiça nos impostos em si mesmo, o que não impede que haja também sua injustiça. Contudo, essa afirmação não deve ser tomada como uma chancela, para a defesa do imposto em toda situação particular. Hayek (1983) adverte para o inevitável caminho que o demasiado apego as autoridades dos reinos e a leniência ao seu poder de coerção podem levar para progressivos avanços em direção ao Caminho da Servidão.

O avanço do Estado totalitário é a volta do arranjo do regime teopolítico, no qual a ordem humana e divina se confunde como apontado por Eric Voegelin (2014), e isto é muito perigoso, pois, como expõe Hayek (2010), o Estado se torna uma instituição que impõe uma "moral", mesmo que não seja a correta.

A teologia católica está longe de afirmar que o imposto é, em todos os casos, moral, mas reconhece a autoridade legitimamente investida. Também recorda que a visão de São Tomás, sobre o imposto, considera um Estado muito menor e mais limitado do que se observa hoje.

Para São Tomás de Aquino, se as coletas, quando não são imoderadas, são lícitas e não configuram pecado, não transgridem a lei natural (DE AQUINO, 2014). "Se, porém, quiserem exigir além do que foi instituído, apenas pelo desejo de possuir ou por causa de desordenadas e imoderadas despesas, isto não lhes é lícito de nenhuma maneira".

A Sagrada Escritura auxilia na conclusão: contanto que os impostos sejam justos, portanto, destinem-se ao bem comum e não tenham nenhuma finalidade que seja imoral, isto é, contra a Lei Natural, podem ser cobrados. São Lucas, no seu evangelho, responde à questão: "Interrogabant autem eum et milites dicentes: "Quid faciemus et nos?". Et ait illis: "Neminem concutiatis neque calumniam faciatis et contenti estote stipendiis vestris." E "Quis militat suis stipendiis umquam?" $(1$ Cor 9,7) 32 . Outrossim, se a cobrança fosse, em todo caso, imoral, São João Batista não haveria respondido aos cobradores de impostos, que perguntaram o que deveriam fazer para se converter, ao serem batizados: "Nihil amplius quam constitutum est vobis, faciatis"33. Mas diria: "Não exijais nada".

Se o Estado, ao cumprir seu dever de proteger as vidas e propriedades de seus súditos, assim como na função de administrar a justiça, deve ser dotado dos meios, que devem estar de acordo com a virtude da justiça- para o bem fazê-la, portanto, pode cobrar impostos dos seus súditos, de modo a cumprir estes fins. Contudo, se as cobranças forem injustas, o Estado torna-se um grupo de salteadores pomposos, com cerimônias de coroação, escudos com símbolos do grupo e elmos adornados. Logo, é necessária certa virtude nos grupos políticos que estão no Estado, ou seja, que tenham a justiça como virtude. Afastada esta virtude dos

\footnotetext{
${ }^{32}$ Bíblia Ave-Maria. Tradução para o português: “Quem, jamais, vai à guerra à sua custa? Quem planta uma vinha e não come do seu fruto? Quem apascenta um rebanho e não se alimenta do leite do rebanho?". Inserido em I Coríntios, 9 (BÍBLIA CATÓLICA ONLINE, s/d. Disponível em: https://www.bibliacatolica.com.br/bibliaave-maria/i-corintios/9/. Acesso em: 22 nov 2019).

33 "Não exijais mais do que vos foi ordenado". Inserido no Evangelho de São Lucas, 9 (BÍBLIA CATÓLICA ONLINE, s/d. Disponível em: https://www.bibliacatolica.com.br/biblia-ave-maria/sao-lucas/3/. Acesso em: 22 nov 2019).
} 
homens, estará, portanto, afastada do governo. Com isso, as podres sementes da tirania foram plantadas.

\section{Referências}

ARISTÓTELES. A Política. Brasília: UNB, 1985.

BENNET, J. The Books of Virtues. Medievalist, 1993. Disponível em: http://www.medievalists.net/2015/05/ the-changing-story-of-cnut-and-the-waves/. Acessado em 25 set 2019.

BBC. Charles I. S/d. Disponível em: http://www.bbc.co.uk/history/historic_figures/charles_i_king.shtml. Acesso em: 25 set 2019.

CHAFUEN, Alejandro. Raíces Cristianas de La Economía de Libre Mercado. Santiago: Fundación para el Progresso, 2009.

CICERO, M. T. Da república. São Paulo: Edipro, 2011.

DE AQUINO, Tomás. Do governo dos judeus à duquesa de Brabante. São Paulo: Edipro. 2014.

DE AQUINO, Tomás. Suma Teológica. Brasil: Ecclesiae, 2016.

DE HIPONA, Agostinho. Cidade de Deus. São Paulo: Fundação Calouste Gulbenkian, 1996.

DE MARIANA, Juan. A Treatise on the Alteration of Money. Michigan: CLP Academic, 2011.

DE SOTO, JESUS HUERTA. La Caída del Imperio Romano. Aula ministrada em Universidad Rey Juan Carlos, em 19 de fevereiro de 2010. Disponível em: https://www.youtube.com/watch?v=6PcaciZean4. Acesso em: 10 mar 2019.

FAORO, Raymundo. Os Donos do Poder: Formação do Patronato Político Brasileiro. São Paulo: Biblioteca Azul, 2001.

G1. No Brasil, segundo o Banco Interamericano de Desenvolvimento, o Estado gasta o equivalente a $42 \%$ do PIB. 2019. Disponível em: https://g1.globo.com/economia/noticia/2019/05/07/estudo-do-bid-diz-que-brasil-gastamuito-e-gasta-mal-ineficiencias-somam-us-68-billoes-por-ano.ghtml. Acesso em: 28 set 2019.

HAYEK, F. A. Law, Lesgislation and Liberty. Grã-Bretanha: Routledge \& Kegan Paul Ltd, 1982.

HAYEK, F.A. O Caminho da Servidão. São Paulo: Instituto Mises, 2010.

HAYEK, F. A. Os Fundamentos da Liberdade. São Paulo: Editora Visão, 1983.

HOPPE, Hans Hermman. Democracia: o Deus que falhou. São Paulo: Instituto Ludwig von Mises Brasil, 2014.

HOPPE, Hans Hermann. From Aristrocracy to Monarchy to Democracy. Alabama: Mises Institute, 2014.

HOBBES, Thomas. Leviatã. São Paulo: Martins Fortes, 2003.

JOÃO PAULO II. Carta enc Centesimus annus. Vaticano: AAS 83, 1991.

LENIN, V. I. Religion. Nova Iorque: International Publisher, 1933. 
LAURES, John. The Political Economy of Juan de Mariana. New York: Fordham University Press, 1928. Disponível em: https://mises-media.s3.amazonaws.com/The\%20Political\%20Economy\%20of\%20Juan\%20De\%20 Mariana_2.pdf. Acessado em: 10 mar 2019.

LOCKE, John. Segundo Tratado sobre o Governo Civil. Rio de Janeiro: Editora Vozes Distribuição, 2006.

MALOONEY, Mike. Seven Stages of Empire - Hidden Secrets of Money. Nova Iorque: Gold and Silver, 2013.

MARX, Karl. Manifesto Comunista: Karl Marx e Friedrich Engels. São Paulo: Editora Bontempo, 2010.

MERQUIOR, José Guilherme. O Liberalismo: Antigo e Moderno. São Paulo: Nova Fronteira. Disponível em: http://www.ie.ufrj.br/intranet/ie/userintranet/hpp/arquivos/040920170406_ JosGuilhermeMerquiorOLiberalismoAntigoeModernoNovaFronteira1991splitmerge.pdf. Acessado em: 25 set 2019.

MORTIMER, Ian. Séculos de Transformações. São Paulo: Bertrand Brasil, 2018.

SUARÉZ, Francisco. Tractatus De Legibus Ac Deo Legislatore. Nabu Press, 2014

SUARÉZ, Francisco. De Iure Gentium. Madrid: C.S.I.C., 1974.

PAUL, Ron. Definindo a Liberdade. São Paulo: Instituto Mises Brasil, 2013.

RICARDO, David. Princípios de Economia Política e Tributação. São Paulo: Editora Nova Cultural Ltda,1996

ROTHBARD, Murray N. Governo e Mercado: a economia da intervenção estatal. São Paulo: Instituto Mises Brasil, 2012.

ROTHBARD, Murray N. Para uma Nova Liberdade: O Manifesto Libertário. São Paulo: Instituto Mises Brasil, 2013.

ROTHBARD, Murray N. A Ética da Liberdade. São Paulo: Instituto Ludwig Von Mises Brasil, 2010.

ROTHBARD, Murray. Economic Thought Before Adam Smith: An Austrian Perspective on History of Economic Thought. Alabama: Mises Institute, 1995.

SAGRADA ESCRITURA. Sagrada Escritura. Vaticano, s/d. Disponível em: http://www.vatican.va/archive/bible/ index_po.htm. Acessado em: 10 mar 2019.

SKOUSEN, W. Cleon. O Comunista Exposto: desvendando o comunismo e restaurando a Liberdade. Campinas: Vide Editorial, 2018.

SMITH, Adam. A Riqueza das Nações: uma investigação sobre a natureza e as causas da riqueza das nações. Rio de Janeiro: Nova Fronteira, 2017.

SOUSA, José Pedro Galvão de. Direito Natural, direito positivo e estado de direito. São Paulo: Editora Revista dos Tribunais, 1977.

SPOONER, Lyssander. Direito Natural ou a Ciência da Justiça. São Paulo: Instituto Rothbard, 1882.

VIII, Bonifacio. Bula Unam Sanctam. S/d. Disponível em: http://www.montfort.org.br/bra/documentos/decretos/ unamsanctam/. Acessado em: 07 mar 2019.

VOEGELIN, Eric. Israel e a Revelação. São Paulo: Editora Loyola, 2014.

VON MISES, MISES, Ludwig von. Ação Humana: Um Tratado de Economia. São Paulo: Instituto Ludwig von Mises Brasil, 2010. 
VON MISES, Ludwig. Socialism: An Economic and Sociological Analysis. Yale: Yale University Press, 1959.

VON MISES, Ludwig. Liberalismo: Segundo a Tradição Clássica. São Paulo: Instituto Mises, 2010.

UOL. Brasileiro trabalha mais de 5 meses no ano para pagar imposto, diz estudo. Disponível em: https://economia. uol.com.br/noticias/redacao/2019/06/03/dias-trabalhados-ano-para-pagar-imposto.htm. Acesso em: 25 set 2019.

RECEBIDO EM: 26/07/2019

APROVADO EM: 01/10/2019 